\title{
Analisis Pemenuhan Persyaratan Ekolabel Global Aquaculture Alliance - Best Aquaculture Practices (GAA-BAP) di Industri Pengolahan Udang PT. XYZ Sidoarjo
}

\section{Compliance Analysis of Ecolabelling Requirements Global Aquaculutre Alliance - Best Aquaculture Practices (GAA-BAP) in Shrimp Processing Industry PT. XYZ Sidoarjo}

\author{
Puji Sugeng Ariadi ${ }^{1)^{*}}$, Yus Isnainita Wahyu ${ }^{2)}$ \\ ${ }^{1}$ Pengawas Perikanan Pada Balai Karantina Ikan, Pengendalian Mutu dan Keamanan Hasil \\ Perikanan Surabaya I \\ 2Program Studi Teknik Pengolahan Produk Perikanan,Politeknik Kelautan dan Perikanan Sidoarjo
}

\author{
Penulis korespondensi : Email: tanyapujisugeng@gmail.com
}

(Diterima Agustus 2020/ Disetujui Juni 2021)

\begin{abstract}
ABSTRAK
Salah satu sertifikasi ekolabel untuk industri pengolahan udang adalah Best Aquaculture Practices dari Global Aquaculture Alliance (GAA-BAP). Indonesia sebagai salah satu produsen udang terbesar dunia, maka berkepentingan dalam penerapan ekolabel GAA-BAP melalui dukungan regulasi dan mendorong perbaikan penerapan ekolabel yang lebih baik di industri pengolahan udang. Penelitian ini bertujuan untuk mengkaji regulasi yang mendukung penerapan ekolabel GAA-BAP dan menganalisis kondisi aktual dalam memenuhi persyaratan ekolabel GAA-BAP. Metode penelitian yang digunakan yaitu metode deskriptif dengan studi kasus pada industri pengolahan udang beku yaitu PT. XYZ Sidoarjo. Metode analisis dalam mengkaji regulasi ekolabel GAA-BAP adalah metode yuridis empiris. Sedangkan metode analisis kondisi aktual dengan cara penilaian kesesuaian di lokasi studi kasus dibandingkan sub-sub klausul standar persyaratan ekolabel GAA-BAP serta penyusunan rekomendasi perbaikan. Hasil yang didapat dari penelitian adalah industri pengolahan udang sudah mematuhi dan menjalankan regulasi yang berlaku di Indonesia dan regulasi internasional khususnya negara-negara tujuan ekspor. Hasil penilaian kesesuaian menunjukkan bahwa PT. XYZ sudah memenuhi $100 \%$ sub klausul kepemilikan hak, $100 \%$ sub klausul sistem manajemen mutu, $75 \%$ sub klausul manajemen karyawan, $100 \%$ sub klausul manajemen limbah dan lingkungan, $93 \%$ sub klausul manajemen keamanan pangan, $90 \%$ sub klausul manajemen verifikasi, $100 \%$ sub klausul sistem ketertelusuran, dan $96 \%$ sudah memenuhi persyaratan tambahan. Rekomendasi perbaikan yang harus dilakukan adalah peningkatan pengawasan fasilitas keselamatan kerja karyawan, melaksanakan program pelatihan penanganan bahan kimia berbahaya, mengimplementasikan prosedur ketahanan pangan, melaksanakan pengujian internal sesuai persyaratan GAA-BAP secara rutin, melakukan audit internal yang mencakup audit sosial dan lingkungan, serta menjamin instalasi limbah dalam kondisi baik untuk operasional.
\end{abstract}

Kata Kunci : Ekolabel, GAA-BAP, Industri pengolahan udang

\begin{abstract}
One of the ecolabel certification for the shrimp processing industry is the Best Aquaculture Practices of the Global Aquaculture Alliance (GAA-BAP). Indonesia, as one of the world's largest shrimp producers, has an interest in implementing the GAA-BAP ecolabel through regulatory support and encouraging improvements in the adoption of a better ecolabel in the shrimp processing industry. This study aims to examine the regulations that support the application of the GAA-BAP ecolabel and analyze the actual conditions in fulfilling the requirements of the GAA-BAP

To Cite this Paper: Ariadi, P., S., Wahyu, Y., I. 2021. Analisis Pemenuhan Persyaratan Ekolabel Global Aquaculture Alliance - Best Aquaculture Practices (GAA-BAP) di Industri Pengolahan Udang PT. XYZ Sidoarjo. Samakia: Jurnal IImu Perikanan, 12 (2) : 103114.

Journal Homepage: https://journal.ibrahimy.ac.id/index.php/JSAPI
\end{abstract}


ecolabel. The research method used was descriptive method with case studies in the frozen shrimp processing industry, namely PT. XYZ Sidoarjo. The analytical method in studying the GAA-BAP ecolabel regulation was an empirical juridical method. While the actual condition analysis method was by evaluating the suitability at the case study site compared to the standard sub-clauses of the GAA-BAP ecolabel requirements and making recommendations for improvement. The results obtained from the study are the shrimp processing industry has complied with and implemented regulations in force in Indonesia and international regulations, especially export destination countries. The suitability assessment results show that PT. XYZ meets $100 \%$ ownership rights subclauses, $100 \%$ quality management system sub-clauses, $75 \%$ employee management subclauses, $100 \%$ waste and environmental management sub-clauses, $93 \%$ food safety management sub-clauses, $90 \%$ verification management sub-clauses, $100 \%$ of the traceability system clause, and $96 \%$ have met the additional requirements. Recommendations for improvement that need to be done are to increase supervision of employee safety facilities, carry out training programs for handling hazardous chemicals, implement food security procedures, carry out internal testing according to GAA-BAP requirements regularly, conduct internal audits that include social and environmental audits, and guarantee installation waste in good condition for operations.

Keywords : Ecolabel, GAA-BAP, Shrimps processing industry.

\section{PENDAHULUAN}

Udang mendominasi lebih dari 40 persen dari produk perikanan ekspor dengan negara tujuan utama adalah Jepang dan Amerika Serikat (Simamora, 2014). Menurut KKP (2016) komoditas udang mengalami peningkatan nilai ekspor dibanding tahun 2015 yaitu sebesar 6,95 persen, kepiting-rajungan naik 3,91 persen dan komoditas cumi, sotong, gurita naik sebesar 58,62 persen. Salah satu permasalahan yang dihadapi dalam rangka pengembangan industri pengolahan perikanan adalah masih lemahnya jaminan mutu dan keamanan hasil diantaranya adalah penerapan Hazard Analysis and Critical Control Point (HACCP), Bioterrorism Act, sanitasi kekerangan, cemaran logam berat dan histamin pada tuna dan penerapan sertifikasi ramah lingkungan atau ekolabel (Bappenas, 2016).

Menurut ISO 14020 (2000) bahwa ekolabel adalah suatu pernyataan atau klaim yang menunjukkan aspek lingkungan suatu produk dan atau jasa dapat berupa pernyataan, simbol atau gambar pada label produk atau kemasan, literatur produk, bulletin teknis, dan di iklan atau publikasi. Salah satu sertifikasi ekolabel untuk industri pengolahan udang adalah Best Aquaculture Practices dari Global Aquaculture Alliance yang disingkat GAA-BAP yang bertujuan untuk mempromosikan praktik-praktik yang bertanggung jawab di rantai industri budidaya perikanan dengan difokuskan pada konversi keanekaragaman hayati dan masalah lingkungan, sosial, keamanan pangan, dan ketertelusuran (Lee dan Conelly, 2006).

Pentingnya sertifikat ekolabel GAA-BAP adalah untuk memenuhi ketentuan pasar ekspor dan mendukung kebijakan kea rah pengelolaan perikanan yang bertanggung jawab dan berkelanjutan. Peran industri dan kebijakan publik suatu negara sangat mempengaruhi pelaksanaan ekolabel perikanan dimana pengelolaan perikanan melalui skema ekolabel membutuhkan dukungan pemerintah melalui kebijakan atau regulasi. Adanya komitmen kuat memenuhi persyaratan sesuai standar internasional, sehingga perlu kajian regulasi terkait dalam rangka mendukung penerapan ekolabel GAA-BAP khususnya pada industri pengolahan hasil perikanan untuk komoditas udang hasil budidaya (Ingrid et al., 2014).

Ekolabel GAA-BAP di Indonesia sudah diterapkan oleh beberapa rantai industri budidaya mulai dari pabrik pakan, pembenihan (hatchery), tambak dan industri pengolahan. Namun bila dibandingkan dengan negara-negara pesaing dengan pasar ekspor utama adalah Amerika Serikat, maka industri di Indonesia masih lebih rendah dalam penerapan ekolabel GAA-BAP. Perusahaan pakan, pembenihan udang, tambak dan industri pengolahan di India yang tersertifikasi GAA-BAP meningkat tajam menjadi 334, Thailand menjadi 283 fasilitas, Vietnam menjadi 160 fasilitas, sedangkan Indonesia hanya 85 fasilitas pada tahun 2018 (Annonymous, 2018). Data tersebut menunjukkan walaupun belum sepenuhnya pelaku usaha di Indonesia menerapkan ekolabel, tetapi pasar internasional sudah mengetahui industri udang di Indonesia sudah menerapkan GAABAP. Oleh karena itu, untuk mendorong penerapan sistem ekolabel yang lebih baik dan

To Cite this Paper: Ariadi, P., S., Wahyu, Y., I. 2021. Analisis Pemenuhan Persyaratan Ekolabel Global Aquaculture Alliance - Best Aquaculture Practices (GAA-BAP) di Industri Pengolahan Udang PT. XYZ Sidoarjo. Samakia: Jurnal IImu Perikanan, 12 (2) : $103-$ 114.

Journal Homepage: https://journal.ibrahimy.ac.id/index.php/JSAPI 
menciptakan perbaikan secara terus menerus, diperlukan penilaian pemenuhan persyaratan sistem ekolabel GAA-BAP untuk industri pengolahan udang yang sudah mendapatkan sertifikasi. Penelitian ini bertujuan untuk mengkaji regulasi yang mendukung penerapan ekolabel GAA-BAP di industri pengolahan udang budidaya dan menganalisis kondisi aktual di perusahaan pengolahan udang dalam memenuhi persyaratan ekolabel GAA-BAP. Manfaat yang diharapkan yaitu kontribusi hasil pemikiran secara ilmiah bagi pelaku usaha khususnya yang bergerak di Industri pengolahan udang dalam mengembangkan penerapan sistem pelabelan ramah lingkungan.

\section{METODE}

Penelitian dilakukan pada bulan Oktober sampai dengan Desember 2019. Lokasi studi kasus pada salah satu industri pengolahan hasil perikanan dari bahan baku udang vannamei hasil budidaya (Litopenaeus vannamei) menjadi produk akhir dalam bentuk udang mentah beku (frozen raw shrimp) yaitu PT. XYZ di Sidoarjo. Metode penelitian yang digunakan yaitu metode deskriptif dengan menggunakan teknik survei. Data primer diperoleh secara langsung dengan melaksanakan pengamatan dan pencatatan dari hasil observasi di lokasi penelitian dan wawancara mendalam (indepth interview) dengan pihak berkompeten baik pihak internal dan eksternal perusahaan serta melalui Focus Group Discusion (FGD) kepada pihak perusahaan. Data sekunder diperoleh melalui literatur, jurnal, penelitian sebelumnya, buku, internet, dan instansi terkait. Teknik penentuan responden dalam penelitian ini dilakukan secara purposive sampling dengan pertimbangan tertentu oleh peneliti. Teknik purposive sampling adalah teknik untuk menentukan sampel dengan beberapa pertimbangan tertentu dengan tujuan agar data yang diperoleh bisa lebih representatif (Sugiyono, 2010).

Penelitian mencakup pemenuhan regulasi terkait persyaratan ekolabel GAA-BAP di industri pengolahan udang budidaya dan penilaian kesesuaian kondisi aktual penerapan Ekolabel GAABAP. Metode analisis dalam pemenuhan regulasi terkait persyaratan ekolabel GAA-BAP adalah metode yuridis empiris yaitu metode yang membahas berlakunya ketentuan hukum atau regulasi serta kenyataan yang terjadi di masyarakat (Waluyo, 2002).

Penilaian kesesuaian dilakukan dengan menilai antara kondisi aktual penerapan ekolabel di industri pengolahan udang dengan standar persyaratan ekolabel GAA-BAP. Hasil penilaian dikuantitatifkan menggunakan daftar periksa berdasarkan Standard BAP For Processing Plants Revisi 4.2 yang terdiri dari 7 klausul utama dan 50 sub klausul serta 5 persyaratan tambahan. Klausul utama meliputi kepemilikan hak, sistem manajemen mutu, manajemen karyawan, manajemen limbah dan lingkungan, manajemen keamanan pangan, manajemen verifikasi dan ketertelusuran. Menurut Zamrudi et.al (2014) penilaian untuk kesesuaian persyaratan melalui tahapan yaitu (a) menggunakan skala 0, 1 dan 2 dengan ketentuan adalah nilai 2 apabila seluruh persyaratan diimplementasikan, nilai 1 apabila sebagian persyaratan diimplementasikan, dan nilai 0 apabila semua persyaratan belum diimplementasikan; (b) persentase pemenuhan persyaratan dihitung dari jumlah nilai pemenuhan sub-klausul dibagi nilai penuh sub klausul dikalikan 2 yang merupakan konstanta apabila seluruh persyaratan subklausul sudah diimplementasikan, dan (c) penyusunan rekomendasi perbaikan untuk pemenuhan persyaratan.

\section{HASIL DAN PEMBAHASAN}

\section{Pemenuhan Regulasi Nasional dan Internasional dalam Penerapan Ekolabel GAA-BAP di Industri Pengolahan Udang}

Secara rinci pemenuhan regulasi Nasional dan dokumen perizinan yang dipersyaratakan dalam penerapan ekolabel GAA-BAP di industri pengolahan udang PT. XYZ Sidoarjo disajikan pada Tabel 1. Sesuai Tabel 1 bahwa pemenuhan regulasi nasional mencakup regulasi tentang penggunaan lahan dan air untuk menjalankan usaha pengolahan udang beku, regulasi terkait perizinan kegiatan usaha dan operasional perusahaan, dan regulasi terkait perizinan lingkungan. PT. XYZ berlokasi di Sidoarjo sehingga harus menerapkan regulasi yang berlaku di Indonesia. Pemenuhan regulasi terkait usaha dan operasional meliputi regulasi bidang perdagangan; perpajakan; industri; perikanan dan keamanan pangan; serta keselamatan kerja. Pemenuhan regulasi terkait perizinan lingkungan sudah memenuhi ketentuan yang tercantum dalam UU Nomor 32 Tahun 2009 tentang Perlindungan dan Pengelolaan Lingkungan Hidup khususnya Pasal 36 ayat (1) yang menyebutkan bahwa setiap usaha dan/atau kegiatan yang wajib AMDAL atau UKLUPL wajib memiliki izin lingkungan.

To Cite this Paper: Ariadi, P., S., Wahyu, Y., I. 2021. Analisis Pemenuhan Persyaratan Ekolabel Global Aquaculture Alliance - Best Aquaculture Practices (GAA-BAP) di Industri Pengolahan Udang PT. XYZ Sidoarjo. Samakia: Jurnal IImu Perikanan, 12 (2) : 103114.

Journal Homepage: https://journal.ibrahimy.ac.id/index.php/JSAPI 
Pemenuhan regulasi yang berlaku di Indonesia menjadi salah satu bukti bahwa di Indonesia sudah ada kebijakan atau peraturan yang mendukung dalam penerapan ekolabel atau pelabelan ramah lingkungan. Menurut Pramoda dan Putri (2017) bahwa regulasi nasional Indonesia sebagai pendukung penerapan ekolabel sudah teridentifikasi, tetapi harus diakui bahwa pengaturan regulasi di Indonesia belum spesifik.

Tabel 1. Pemenuhan Regulasi Nasional dan Dokumen Perizinan dalam Penerapan Ekolabel GAA-BAP

\begin{tabular}{|c|c|c|}
\hline No. & Regulasi & Dokumen Perizinan \\
\hline 1. & $\begin{array}{l}\text { Undang Undang No. } 05 \text { Tahun } 1960 \text { tentang Peraturan } \\
\text { Dasar Pokok-pokok Agraria }\end{array}$ & $\begin{array}{l}\text { Sertifikat Hak Guna Bangunan } \\
\text { (HGB) }\end{array}$ \\
\hline 2. & $\begin{array}{l}\text { Undang Undang No. } 28 \text { Tahun } 2002 \text { tentang Bangunan } \\
\text { Gedung }\end{array}$ & Izin Mendirikan Bangunan (IMB) \\
\hline 3. & $\begin{array}{l}\text { Undang Undang No. } 07 \text { Tahun } 2004 \text { tentang Sumber } \\
\text { Daya Air }\end{array}$ & $\begin{array}{l}\text { Surat Izin Pengambilan Air } \\
\text { Tanah (SIPA) }\end{array}$ \\
\hline 4. & $\begin{array}{l}\text { a. Undang Undang No. } 07 \text { Tahun } 2014 \text { tentang } \\
\text { Perdagangan } \\
\text { b. Permendag No. 07/M-DAG/PER/2/2017 tentang } \\
\text { Penerbitan Surat Izin Usaha Perdagangan }\end{array}$ & $\begin{array}{l}\text { - Surat Izin Usaha } \\
\text { Perdagangan (SIUP) } \\
\text { - Tanda Daftar Perusahaan } \\
\text { (TDP) }\end{array}$ \\
\hline 5. & $\begin{array}{l}\text { Undang Undang No. } 06 \text { Tahun } 1983 \text { sebagaimana telah } \\
\text { diubah dengan UU No. } 16 \text { Tahun } 2009 \text { tentang } \\
\text { Ketentuan Umum dan Tata Cara Perpajakan }\end{array}$ & $\begin{array}{l}\text { Nomor Pokok Wajib Pajak } \\
\text { (NPWP) }\end{array}$ \\
\hline 6. & $\begin{array}{l}\text { Undang Undang No. } 03 \text { Tahun } 2014 \text { tentang } \\
\text { Perindustrian }\end{array}$ & Izin Usaha Industri (IUI) \\
\hline 7. & $\begin{array}{l}\text { Undang Undang Nomor } 31 \text { Tahun } 2004 \text { sebagaimana } \\
\text { telah diubah dengan Undang Undang No. } 45 \text { Tahun } \\
2009 \text { tentang Perikanan }\end{array}$ & $\begin{array}{l}\text { - Izin Usaha Perikanan (IUP) } \\
\text { - Sertifikat Kelayakan } \\
\text { Pengolahan (SKP) } \\
\text { - Sertifikat HACCP }\end{array}$ \\
\hline 8. & $\begin{array}{l}\text { Undang Undang No. } 30 \text { Tahun } 2009 \text { tentang } \\
\text { Ketenagalistrikan }\end{array}$ & Izin Operasi Genset \\
\hline 9. & $\begin{array}{l}\text { a. Undang Undang No. } 1 \text { Tahun } 1970 \text { tentang } \\
\text { Keselamatan Kerja } \\
\text { b. Peraturan Menteri Tenaga Kerja No. } 31 \text { Tahun } 2015 \\
\text { tentang Pengawasan Instalasi Penyalur Petir }\end{array}$ & Izin Penyalur Petir \\
\hline 10. & $\begin{array}{l}\text { Undang Undang No. } 32 \text { Tahun } 2009 \text { tentang } \\
\text { Perlindungan dan Pengelolaan Lingkungan Hidup } \\
\text { (PPLH) }\end{array}$ & $\begin{array}{l}\text { Dokumen Upaya Pengelolaan } \\
\text { dan Upaya Pemantauan } \\
\text { Lingkungan Hidup (UKL-UPL) }\end{array}$ \\
\hline 11. & $\begin{array}{l}\text { Peraturan Pemerintah No. } 27 \text { Tahun } 2012 \text { tentang Izin } \\
\text { Lingkungan }\end{array}$ & $\begin{array}{l}\text { Izin Pembuangan Limbah Cair } \\
\text { (IPLC) }\end{array}$ \\
\hline 12. & $\begin{array}{l}\text { Peraturan Pemerintah No. } 82 \text { Tahun } 2001 \text { tentang } \\
\text { Pengelolaan Kualitas Air dan Pengendalian Pencemaran }\end{array}$ & $\begin{array}{l}\text { Izin Penyimpanan Sementara } \\
\text { Limbah Bahan Berbahaya dan } \\
\text { Beracun (B3) }\end{array}$ \\
\hline 13. & $\begin{array}{l}\text { Peraturan Pemerintah No. } 18 \text { Tahun } 1999 \text { tentang } \\
\text { Pengelolaan Limbah Bahan Berbahaya dan Beracun }\end{array}$ & $\begin{array}{l}\text { Izin Pengangkutan Limbah B3 } \\
\text { atas nama PT. Larashatiku } \\
\text { Environmental }\end{array}$ \\
\hline
\end{tabular}

Regulasi internasional yang menjadi acuan utama Industri Pengolahan Ikan atau udang (UPI) dalam menerapkan ekolabel GAA-BAP dan wajib terdokumentasi di perusahaan tersebut antara lain:

1. Global Food Safety Initiative (GFSI) Guidance Document yaitu dokumen panduan dari lembaga GFSI untuk menentukan sertifikasi atau pengakuan penerapan sistem manajemen keamanan pangan yang salah satu didalamnya adalah penerapan GAA-BAP.

2. The International Organization of Standardization (ISO) 9000 : 2015 Quality Managemen Systems - Fundamentals and vocabulary yaitu standar internasional sistem manajemen mutu - dasar-dasar dan kosakata.

3. The International Organization of Standardization (ISO) 9001 : 2015 Quality Managemen Systems - Requirements yaitu standar internasional sistem manajemen mutu - Persyaratan.

To Cite this Paper: Ariadi, P., S., Wahyu, Y., I. 2021. Analisis Pemenuhan Persyaratan Ekolabel Global Aquaculture Alliance - Best Aquaculture Practices (GAA-BAP) di Industri Pengolahan Udang PT. XYZ Sidoarjo. Samakia: Jurnal IImu Perikanan, 12 (2) : $103-$ 114.

Journal Homepage: https://journal.ibrahimy.ac.id/index.php/JSAPI 
4. The International Organization of Standardization (ISO) 19011 : 2011 Guidelines for quality and/or environmental management system auditing yaitu panduan audit sistem manajemen mutu dan/atau lingkungan.

5. Regulation United States Food and Drug Administration (FDA) No. Code of Federal Regulation (CFR) 123 Fish and Fishery Products Hazards and Control Guidance Fourth Edition - April 2011 yaitu Pedoman Bahaya dan Kontrol Ikan dan Produk Perikanan yang memuat secara rinci standar Good Manufacturing Practices atau cara berproduksi yang baik produk pangan khususnya produk perikanan. Peraturan ini tidak hanya memuat prinsip-prinsip HACCP, tetapi juga standar bahaya kimia, fisik, dan mikrobiologi untuk setiap jenis maupun spesies ikan, serta untuk masing-masing proses pengolahannya.

6. Council Directive CD/98/83/EC of 03 November 1998 on the quality of water intended for human consumption yaitu persyaratan dari Uni Eropa tentang standar air minum yang harus dipenuhi oleh proses produksi pada industri makanan termasuk industri pengolahan hasil perikanan.

7. Regulation European Communities (EC) No. 178/2002 of 28 January 2002 laying down the general and requirements of food law, establishing the European Food Safety Authority and laying down procedures in matters of food safety yaitu ketentuan bagi pelaku usaha makanan yang dipasarkan di Uni Eropa harus memenuhi ketentuan terhadap UU Pangan, penelusuran dan tanggung jawab.

8. Regulation European Communities (EC) No. 1881/2006 of 19 December 2006 setting maximum levels for certain contaminants in foodstuffs yaitu ketentuan yang berisi tentang ekspor bahan makanan ke Uni Eropa harus memenuhi peraturan perlindungan konsumen dan tidak mengandung kontaminan pada batas yang dapat mengancam kesehatan manusia.

9. Regulation European Communities (EC) No. 852/2004 of 29 April 2004 on the hygiene of foodstuffs yaitu ketentuan produk perikanan dan hasil budidaya untuk konsumsi manusia harus mematuhi persyaratan kebijakan kesehatan negara, sertifikat kesehatan dan control kesehatan.

10. Regulation European Communities (EC) No. 2073/2005 of 15 November 2005 on microbiological criteria of foodstuffs yaitu ketentuan atau standar kandungan mikobiologi untuk produk makanan termasuk produk perikanan yang diekspor ke Uni Eropa.

11. Global Aquaculture Alliance Best Aquaculture Practices (GAA-BAP) For Seafood Processing Plants Standards Issue 4 Revision 2 December 2015 yaitu panduan standar penerapan ekolabel GAA-BAP untuk industri pengolahan hasil perikanan.

12. United States Food and Drug Administration (FDA) Bacteriological Analytical Manual (BAM), $B A M$ 4: Enumeration of Escherichia coli and the Coliform Bacteria yaitu ketentuan cara pengujian dan pembacaan hasil pengujian bakteri E.coli dan Coliform untuk produk perikanan yang diekspor ke USA.

13. Canadian Food Inspection Agency Standards and Methods Manual (2013) Appendix 1A CFIA Aquaculture Therapeutant Residue Monitoring yaitu daftar referensi yang dijadikan acuan tentang monitoring residu obat dari produk perikanan hasil budidaya yang akan diekspor ke negara Kanada.

14. Standard Codex Alimentarius Commission/Recommended International Code of Practice (CAC/RCP) 1-1969 Revisi 4 Tahun 2003 tentang Prinsip Dasar tentang Keamanan Pangan atau Penerapan Hazard Analysis and Critical Control Point (HACCP).

15. Regulation International Finance Corporation (IFC) Environmental, Health, and Safety Guidelines Fish Processing yaitu pedoman umum lingkungan, kesehatan dan keselamatan kerja di industri.

PT. XYZ sudah mematuhi dan menjalankan peraturan atau regulasi yang berlaku di Indonesia dan regulasi internasional khususnya negara-negara tujuan ekspor. Hal ini sesuai GAA (2015) bahwa standar ekolabel GAA-BAP mewajibkan bahwa setiap industri pengolahan hasil perikanan mematuhi dan menerapkan regulasi yang berlaku. Industri pengolahan hasil perikanan yang akan mengajukan penerapan ekolabel GAA-BAP harus mengetahui, terus memperbarui, dan mematuhi semua undang-undang terkait kedua negara meliputi negara tempat mereka beroperasi dan negara tujuan ekspor termasuk didalamnya peraturan keamanan pangan.

To Cite this Paper: Ariadi, P., S., Wahyu, Y., I. 2021. Analisis Pemenuhan Persyaratan Ekolabel Global Aquaculture Alliance - Best Aquaculture Practices (GAA-BAP) di Industri Pengolahan Udang PT. XYZ Sidoarjo. Samakia: Jurnal IImu Perikanan, 12 (2) : $103-$ 114.

Journal Homepage: https://journal.ibrahimy.ac.id/index.php/JSAPI 
Penilaian kesesuaian kondisi aktual dalam pemenuhan persyaratan Penerapan Ekolabel GAA-BAP

\section{Kepemilikan Hak}

Hasil penilaian kondisi aktual untuk pemenuhan klausul kepemilikian hak menunjukkan bahwa PT. XYZ sudah mengimplementasikan $100 \%$. Kepemilikan hak meliputi perizinan penggunaan lahan dan air, perizinan kegiatan usaha dan operasional, dan perizinan lingkungan. Menurut GAA (2008) bahwa perusahaan pengolahan harus mematuhi peraturan lokal terkait lingkungan dan ekspor produk serta harus bisa menunjukkan izin legal untuk penggunaan lahan, penggunaan air, kontruksi dan operasi produksi.

\section{Sistem Manajemen Mutu}

Hasil penilaian terhadap sub klausul sistem manajemen mutu penerapan ekolabel GAA-BAP di PT. XYZ disajikan pada Tabel 2. Tabel 2 menunjukkan bahwa PT. XYZ sudah mengimplementasikan sub klausul sistem manajemen mutu dalam penerapan ekolabel GAA-BAP atau persentasenya sudah mencapai $100 \%$ dari keseluruhan persyaratan sub klausul. Sub klausul sistem manajemen mutu dalam penerapan ekolabel GAA-BAP mengacu pada referensi sistem manajemen mutu yaitu ISO 9001:2008. Menurut Arifin (2013) bahwa sertifikasi GAA-BAP merupakan salah satu skema sertifikasi pada unit pengolahan ikan yang mengacu pada ISO 9001:2008 tentang sistem manajemen mutu; ISO 22000:2005 tentang sistem manajemen keamanan pangan; dan regulasi CAC/RCP 1-1969 Revisi 4 Tahun 2003 tentang Penerapan HACCP.

Tabel 2. Hasil Penilaian Klausul Sistem Manajemen Mutu dalam Penerapan Ekolabel GAA-BAP

\begin{tabular}{rlccc}
\hline Kode $^{*}$ & \multicolumn{1}{c}{ Sub Klausul } & Standar & Aktual & \% Pemenuhan \\
\hline 2.1 & Pemenuhan persyaratan umum & 2 & 2 & 100 \\
2.2 & Manual dokumen mutu & 2 & 2 & 100 \\
2.3 & Kebijakan mutu & 2 & 2 & 100 \\
2.4 & Tanggung jawab manajemen & 2 & 2 & 100 \\
2.5 & Komitmen manajemen & 2 & 2 & 100 \\
2.6 & Manajemen sumber daya & 2 & 2 & 100 \\
2.7 & Tinjauan manajemen & 2 & 2 & 100 \\
2.8 & Sistem pengadaan bahan baku & 2 & 2 & 100 \\
2.9 & Pelayanan ke pihak ketiga & 2 & 2 & 100 \\
2.10 & Supplier dan monitoringnya & 2 & 2 & 100 \\
2.11 & Pengendalian dokumen & 2 & 2 & 100 \\
2.12 & Pemeliharaan Prosedur & 2 & 2 & 100 \\
2.13 & Pencatatan & 2 & 2 & 100 \\
2.14 & Tindakan korektif & 2 & 2 & 100 \\
2.15 & Pengendalian produk cacat & 2 & 2 & 100 \\
2.16 & Pengendalian keamanan & 2 & 2 & 100 \\
2.17 & Penarikan produk & 2 & 2 & 100 \\
2.18 & Prosedur keluhan pelanggan & 2 & 2 & 100 \\
\hline & TOTAL & 36 & 36 & 100 \\
\hline
\end{tabular}

Sumber: Analisis Data Primer, 2019

Keterangan: *) Standar GAA-BAP Issue 4.2

\section{Manajemen Karyawan}

Hasil penilaian kondisi aktual terhadap pemenuhan sub klausul manajemen karyawan menunjukkan bahwa PT. XYZ sudah menerapkan $75 \%$ dari persyaratan dalam penerapan ekolabel GAA-BAP. Hasil penilaian sub klausul manajemen karyawan disajikan pada Tabel 3.

Tabel 3. Hasil Penilaian Klausul Manajemen Karyawan dalam Penerapan Ekolabel GAA-BAP

\begin{tabular}{clccc}
\hline Kode $^{*}$ & Sub Klausul & Standar & Aktual & \% Pemenuhan \\
\hline 3.1 & Fasilitas karyawan & 2 & 2 & 100 \\
3.2 & Peralatan dan pakaian pelindung karyawan & 2 & 1 & 50 \\
3.3 & Perawatan medis & 2 & 2 & 100 \\
\hline 3.4 & Pelatihan karyawan & 2 & 1 & 50 \\
\hline & TOTAL & $\mathbf{8}$ & $\mathbf{6}$ & $\mathbf{7 5}$
\end{tabular}

Sumber: Analisis Data Primer, 2019

Keterangan: *) Standar GAA-BAP Issue 4.2

To Cite this Paper: Ariadi, P., S., Wahyu, Y., I. 2021. Analisis Pemenuhan Persyaratan Ekolabel Global Aquaculture Alliance - Best Aquaculture Practices (GAA-BAP) di Industri Pengolahan Udang PT. XYZ Sidoarjo. Samakia: Jurnal IImu Perikanan, 12 (2) : $103-$ 114.

Journal Homepage: https://journal.ibrahimy.ac.id/index.php/JSAPI 
Penilaian kondisi aktual sub klausul 3.2 menunjukkan bahwa karyawan di daerah penyimpanan es curai belum dilengkapi jaket pelindung seperti karyawan yang bekerja di area gudang beku atau cold storage dan karyawan di bagian mekanik tidak menggunakan sepatu bot sebagai pelindung keselamatan bekerja, padahal perusahaan sudah menyediakan fasilitas karyawan tersebut. Kondisi ini belum sesuai OSHS (2014) bahwa pakaian pelindung berguna melindungi sebagian badan atau seluruhnya dari bahaya pekerjaannya di temperatur dingin, secara mendasar pakaian dibuat tiga prinsip yaitu adanya sistem penyekatan (insulasi), pelapisan dan ventilasi. Worksafe (2008) menambahkan pakaian pelindung menjadi salah satu alat pelindung yang porsinya lebih besar untuk mencegah terjadinya hipotermia atau penurunan suhu tubuh dari suhu tubuh normal yang merupakan salah satu efek cold stress.

Pelatihan karyawan (sub klausul 3.4) sudah dilaksanakan oleh perusahaan yang meliputi cara penanganan terpapar bahan kimia, senyawa bahan bakar dan racun lainnya, namun perusahaan belum mengadakan pelatihan tentang cara penanganan limbah bahan berbahaya beracun. Menurut GAA (2015) bahwa perusahaan pemohon penerapan GAA-BAP harus memiliki program pelatihan untuk memastikan pekerja menangani bahan kimia berbahaya, bahan bakar atau zat beracun lainnya dengan benar.

\section{Manajemen Limbah dan Lingkungan}

Hasil penilaian terhadap kondisi aktual untuk sub klausul manajemen limbah dan lingkungan dalam penerapan ekolabel GAA-BAP di PT. XYZ disajikan pada Tabel 4.

Tabel 4. Hasil Penilaian Klausul Manajemen Limbah dan Lingkungan dalam Penerapan Ekolabel GAA-BAP

\begin{tabular}{rlccc}
\hline Kode $^{*}$ & \multicolumn{1}{c}{ Sub Klausul } & Standar & Aktual & $\begin{array}{c}\% \\
\text { Pemenuhan }\end{array}$ \\
\hline 4.1 & Sistem penyimpanan dan pembuangan bahan & 2 & 2 & 100 \\
& pembantu & 2 & 2 & 100 \\
\hline 4.2 & Manajemen limbah padat dan limbah cair & 2 & $\mathbf{4}$ & $\mathbf{1 0 0}$ \\
\hline
\end{tabular}

Sumber: Analisis Data Primer, 2019

Keterangan: *) Standar GAA-BAP Issue 4.2

Tabel 6 menjelaskan bahwa sub klausul manajemen limbah dan lingkungan dalam penerapan ekolabel GAA-BAP sudah diterapkan $100 \%$ dari persyaratan. Penyimpanan produk kimia, bahan bakar, pelumas, dan senyawa non pangan lainnya serta senyawa beracun di lingkungan PT. XYZ sudah diberi label dengan benar dan penyimpannya terkunci dengan baik serta dikeluarkan oleh orang yang berwenang saja mengikuti prosedur operasional standar perusahaan. Menurut National Seafood HACCP Alliance (2000) bahwa senyawa dan bahan kimia beracun harus diberi label, disimpan dengan baik dan digunakan sesuai petunjuk.

\section{Manajemen Keamanan Pangan}

Hasil penilaian kondisi aktual terhadap pemenuhan sub klausul manajemen keamanan pangan menunjukkan bahwa PT. XYZ sudah menerapkan $93 \%$ dari persyaratan ekolabel GAA-BAP. Hasil penilaian sub klausul manajemen keamanan pangan disajikan pada Tabel 5.

Sistem keamanan pangan yang dijalankan oleh PT. XYZ mengacu pada dokumen atau panduan sistem jaminan mutu dan keamanan hasil perikanan berdasarkan konsep HACCP atau Program Manajemen Mutu Terpadu (PMMT). Berdasarkan Peraturan Menteri Kelautan dan Perikanan Nomor 51/Permen-KP/2018 bahwa sertifikat PMMT adalah sertifikat yang diberikan pelaku usaha industri pengolahan ikan atau udang (UPI) yang telah menerapkan sistem jaminan mutu dan keamanan hasil perikanan. Adanya sistem manajemen keamanan pangan HACCP sangat membantu dalam pemenuhan persyaratan penerapan ekolabel GAA-BAP. Menurut Mercan dan Bucak (2013) bahwa perusahaan yang menerapkan HACCP atau ISO 9001 sebelumnya, akan lebih mudah dalam menerapkan standar-standar internasional lainnya.

Hasil penilaian kondisi aktual menunjukkan bahwa terdapat sub klausul yang belum diterapkan sepenuhnya yaitu daya tahan produk (sub klausul 5.4) dan pengawasan permukaan yang kontak dengan produk (sub klausul 5.8). Pengendalian daya tahan produk diketahui bahwa perusahaa telah menerapkan tindakan keamanan fasilitas untuk menghindari sabotase, tetapi fasilitas tidak memiliki penilaian risiko ketahanan pangan dari produk yang disimpan. Hal ini tidak sesuai dengan

To Cite this Paper: Ariadi, P., S., Wahyu, Y., I. 2021. Analisis Pemenuhan Persyaratan Ekolabel Global Aquaculture Alliance - Best Aquaculture Practices (GAA-BAP) di Industri Pengolahan Udang PT. XYZ Sidoarjo. Samakia: Jurnal IImu Perikanan, 12 (2) : $103-$ 114.

Journal Homepage: https://journal.ibrahimy.ac.id/index.php/JSAPI 
GAA (2015) bahwa perusahaan harus memiliki sistem dan prosedur penilaian risiko yang terdokumentasi untuk mencegah, mengurangi atau menghilangkan risiko pertahanan makanan dan harus ditinjau minimal setiap tahun.

Pengawasan peralatan yang kontak produk menunjukkan bahwa hasil verifikasi yang berupa pengujian swap atau uji permukaan peralatan sudah meliputi uji Total Plate Count (TPC), bakteri E. coli, Coliform, tetapi UPI belum menguji bakteri Staphylococcus sp. Menurut U.S. Department of Health and Human Services-FDA (2011) bahwa perusahaan pengolahan makanan harus melakukan verifikasi atau pengujian yang mencerminkan upaya yang konsisten untuk menurunkan jumlah mikroba pada permukaan peralatan yang meliputi uji Total Plate Count (TPC), Coliform dan bakteri Staphylococcus.

Tabel 5. Hasil Penilaian Klausul Manajemen Keamanan Pangan dalam Penerapan Ekolabel GAA-

\begin{tabular}{rlccc}
\multicolumn{1}{c}{ Sub Klausul } & BAP & & \\
\hline Kode $^{*}$ & & Standar & Aktual & \% Pemenuhan \\
\hline 5.1 & Sistem keamanan pangan & 2 & 2 & 100 \\
5.2 & Kepatuhan konsep HACCP & 2 & 2 & 100 \\
5.3 & Peninjauan prosedur HACCP & 2 & 2 & 100 \\
5.4 & Daya tahan produk & 2 & 1 & 50 \\
5.5 & Kontruksi area pabrik & 2 & 2 & 100 \\
5.6 & Program pengendalian hewan pengganggu & 2 & 2 & 100 \\
5.7 & Sistem pemasangan lampu & 2 & 2 & 100 \\
5.8 & Peralatan yang kontak produk & 2 & 1 & 50 \\
5.9 & Prosedur sanitasi personel & 2 & 2 & 100 \\
5.10 & Penggunaan air proses & 2 & 2 & 100 \\
5.11 & Penggunaan bahan kimia & 2 & 2 & 100 \\
5.12 & Pencegahan pencemaran produk & 2 & 2 & 100 \\
5.13 & Sistem penyimpanan & 2 & 2 & 100 \\
5.14 & Sistem pencegahan kontaminasi silang & 2 & 2 & 100 \\
5.15 & Pengawasan bahan asing & 2 & 2 & 100 \\
\hline & TOTAL & $\mathbf{3 0}$ & $\mathbf{2 8}$ & $\mathbf{9 3}$ \\
\hline
\end{tabular}

Sumber: Analisis Data Primer, 2019

Keterangan: ${ }^{*}$ Standar GAA-BAP Issue 4.2

\section{Manajemen Verifikasi}

Hasil penilaian terhadap kondisi aktual sub klausul manajemen verifikasi dalam penerapan ekolabel GAA-BAP di PT. XYZ persentase pemenuhannya adalah $90 \%$ seperti tercantum pada Tabel 6.

Tabel 6. Hasil Penilaian Klausul Manajemen Verifikasi dalam Penerapan Ekolabel GAA-BAP

\begin{tabular}{clccc}
\hline Kode $^{*}$ & \multicolumn{1}{c}{ Sub Klausul } & Standar & Aktual & \% Pemenuhan \\
\hline 6.1 & Rilis produk & 2 & 2 & 100 \\
6.2 & Audit internal & 2 & 1 & 50 \\
6.3 & Kalibrasi eksternal (pihak ketiga) & 2 & 2 & 100 \\
6.4 & Pengambilan contoh atau sampling & 2 & 2 & 100 \\
6.5 & Pengujian laboratorium & 2 & 2 & 100 \\
\hline & TOTAL & $\mathbf{1 0}$ & $\mathbf{9}$ & $\mathbf{9 0}$
\end{tabular}

Sumber: Analisis Data Primer, 2019

Keterangan: *) Standar GAA-BAP Issue 4.2

Tabel 6 menunjukkan bahwa hasil penilaian kondisi aktual terhadap pemenuhan sub klausul manajemen verifikasi bahwa PT. XYZ sudah menerapkan sebagian besar atau $90 \%$ dari persyaratan manajemen verifikasi dalam penerapan ekolabel GAA-BAP. Persyaratan atau sub klausul yang belum diterapkan sepenuhnya adalah program audit internal (sub klausul 6.2). Audit internal terbaru sudah dilaksanakan dan dikoordinasikan oleh Manajer QA. Auditor menunjukkan kompetensi yang memadai untuk melakukan audit internal dengan dibuktikan bahwa perusahaan telah membuat program untuk memilih auditor dari organisasi perusahaan dan sudah dilakukan pelatihan untuk mengembangkan kemampuan auditor internal. Namun audit internal belum

To Cite this Paper: Ariadi, P., S., Wahyu, Y., I. 2021. Analisis Pemenuhan Persyaratan Ekolabel Global Aquaculture Alliance - Best Aquaculture Practices (GAA-BAP) di Industri Pengolahan Udang PT. XYZ Sidoarjo. Samakia: Jurnal IImu Perikanan, 12 (2) : $103-$ 114.

Journal Homepage: https://journal.ibrahimy.ac.id/index.php/JSAPI 
mencakup tentang audit sosial dan lingkungan. Hal ini belum sesuai GAA (2015) bahwa program audit internal dibentuk untuk memastikan penerapan sistem manajemen mutu, keamanan pangan, sosial dan audit lingkungan. Ruang lingkup audit untuk setiap fungsi dalam organisasi berdasarkan risiko dan auditor tidak mengaudit departemen mereka sendiri.

\section{Sistem Ketertelusuran}

Penilaian kondisi aktual terhadap pemenuhan sub klausul dari sistem ketertelusuran menunjukkan hasil bahwa PT. XYZ sudah menerapkan $100 \%$ dari persyaratan sistem. Hasil penilaian sub klausul sistem ketertelusuran disajikan pada Tabel 7.

Tabel 7. Hasil Penilaian Klausul Sistem Ketertelusuran dalam Penerapan Ekolabel GAA-

\begin{tabular}{clccc}
\multicolumn{5}{c}{ BAP di PT. XYZ } \\
\hline Kode $^{*}$ & \multicolumn{1}{c}{ Sub Klausul } & Standar & Aktual & \% Pemenuhan \\
\hline 7.1 & Pengendalian dan pengawasan label BAP & 2 & 2 & 100 \\
7.2 & Dokumentasi ketertelusuran & 2 & 2 & 100 \\
7.3 & Elemen ketertelusuran & 2 & 2 & 100 \\
7.4 & Keseimbangan bahan baku dengan produk & 2 & 2 & 100 \\
7.5 & akhir & 2 & 2 & 100 \\
\hline & Dokumentasi atau retensi sampel & $\mathbf{1 0}$ & $\mathbf{1 0}$ & $\mathbf{1 0 0}$
\end{tabular}

Sumber: Analisis Data Primer, 2019

Keterangan: ") Standar GAA-BAP Issue 4.2

PT. XYZ telah menerapkan memiliki dokumentasi data tambak yang sudah pengiriman bahan baku udang segar dari tambak yang sudah memliliki sertifikat BAP ke UPI. Dokumentasi data tambak tersebut antara lain nama pemasok atau supplier, nomor sertifikasi BAP tambak, metode produksi (tambak intensif, super intensif, semi intensif, kolam, dan lain-lain), identifikasi unit produksi, sumber post larva atau bahan penebaran, tanggal pengiriman dan nomor lot, nomor dokumen distribusi atau pengangkutan, penggunaan pakan (jenis dan nomor lot), laporan penggunaan obat, serta data pengujian untuk keberadaan mikrobiologi, antibiotik dan bahan kimia dalam produk udang segar. Hal tersebut sesuai dengan GAA (2015) bahwa penyimpanan catatan ketertelusuran harus merekam informasi mengenai nama pembudidaya, identifikasi pembudidaya bersertifikat GAABAP, spesies, nomor lot budidaya, identifikasi perusahaan pengolahan yang bersertifikat GAA-BAP, tanggal dan waktu penerimaan produk di pabrik, nomor lot, berat akhir, serta bentuk produk.

\section{Persyaratan Tambahan}

Penilaian kondisi aktual terhadap pemenuhan persyaratan tambahan sebagaimana menunjukkan bahwa PT. XYZ sudah menerapkan 96\% dari persyaratan, artinya bahwa sebagian besar persyaratan tambahan dalam penerapan ekolabel GAA-BAP sudah dilaksanakan yang mencakup manajemen kewajiban sosial, manajemen limbah, verifikasi ketertelusuran, hasil pengujian produk dari laboratorium eksternal dan pengujian kualitas air. Hasil penilaian terhadap klausul persyaratan tambahan dalam penerapan ekolabel GAA-BAP di PT. XYZ disajikan pada Tabel 8.

\footnotetext{
To Cite this Paper: Ariadi, P., S., Wahyu, Y., I. 2021. Analisis Pemenuhan Persyaratan Ekolabel Global Aquaculture Alliance - Best Aquaculture Practices (GAA-BAP) di Industri Pengolahan Udang PT. XYZ Sidoarjo. Samakia: Jurnal Ilmu Perikanan, 12 (2) : $103-$ 114

Journal Homepage: https://journal.ibrahimy.ac.id/index.php/JSAPI
} 
Tabel 8. Hasil Penilaian Klausul Persyaratan Tambahan dalam Penerapan Ekolabel GAABAP

\begin{tabular}{|c|c|c|c|c|c|c|}
\hline & \multirow{3}{*}{$\begin{array}{l}\text { Persyaratan } \\
\text { Manajemen } \\
\text { Kewajiban } \\
\text { Sosial }\end{array}$} & & Variabel & \multirow{2}{*}{$\frac{\text { Standar }}{2}$} & \multirow{2}{*}{$\begin{array}{c}\text { Aktual } \\
2\end{array}$} & \multirow{2}{*}{$\begin{array}{c}\text { \% Pemenuhan } \\
100\end{array}$} \\
\hline \multirow[t]{9}{*}{$\mathrm{I}}$. & & 1. & $\begin{array}{l}\text { Kepatuhan Regulasi } \\
\text { Ketenagakerjaan }\end{array}$ & & & \\
\hline & & 2. & Upah, jam kerja, dan status & 2 & 2 & 100 \\
\hline & & 3. & Jam kerja & 2 & 2 & 100 \\
\hline & & 4. & Keterikatan pekerja & 2 & 2 & 100 \\
\hline & & 5. & Tenaga kerja anak & 2 & 2 & 100 \\
\hline & & & $\begin{array}{l}\text { Kesehatan dan keselamatan } \\
\text { kerja }\end{array}$ & 2 & 2 & 100 \\
\hline & & & $\begin{array}{l}\text { Kontrak dan syarat } \\
\text { pekerjaan }\end{array}$ & 2 & 2 & 100 \\
\hline & & 8. & Diskriminasi dan intimidasi & 2 & 2 & 100 \\
\hline & & & Kebebasan berkelompok & 2 & 2 & 100 \\
\hline \multirow[t]{2}{*}{ II. } & $\begin{array}{l}\text { Manajemen } \\
\text { Limbah }\end{array}$ & 1. & $\begin{array}{l}\text { Kepatuhan terhadap } \\
\text { Regulasi }\end{array}$ & 2 & 2 & 100 \\
\hline & & & Rekaman Uji Limbah & 2 & 1 & 50 \\
\hline & \multicolumn{3}{|c|}{ I. Hasil Uji Kualitas Air } & 2 & 2 & 100 \\
\hline \multirow{3}{*}{$\begin{array}{l}\text { IV. } \\
\text { V. }\end{array}$} & Verifikasi Ket & telu & uran & 2 & 2 & 100 \\
\hline & Laboratorium & Sinal & Ketiga & 2 & 2 & 100 \\
\hline & TOTAL & & & 28 & 27 & 96 \\
\hline
\end{tabular}

Sumber: Analisis Data Primer, 2019

Pemenuhan rekaman uji limbah memiliki pemenuhan sebesar $50 \%$ hal ini karena pesyaratan belum sepenuhnya dipenuhi yaitu drive belt di pompa pengolahan air limbah sering mengalami kerusakan sehingga berpotensi mempengaruhi hasil uji limbah. Menurut GAA (2008) perusahaan harus memastikan bahwa peralatan dan mesin pengolahan limbah harus aman, berfungsi dengan baik dan pemeliharaannya harus terjamin.

Rekomendasi Perbaikan untuk Pemenuhan Persyaratan

Rekomendasi perbaikan yang dapat diberikan dalam pemenuhan persyaratan ekolabel GAA-BAP dengan mempertimbangkan hasil penilaian yang ditemukan di PT.XYZ adalah sebagai berikut:

a. Meningkatkan pengawasan penggunaan fasilitas keselamatan kerja karyawan khususnya penggunaan jaket pelindung di area dingin oleh Supervisor Quality Control berkoordinasi dengan Departemen Personalia.

b. Melaksanakan program pelatihan karyawan secara rutin dengan materi tambahan atau materi khusus tentang penanganan bahan kimia berbahaya dan beracun. Program pelatihan tersebut harus dicantumkan dalam Prosedur Operasional Standar (POS) dan hasil pelatihan harus terdokumentasi.

c. Perlu diimplementasikan prosedur ketahanan pangan pada produk yang sudah disimpan yang meliputi prosedur penilaian resiko produk serta harus dicantumkan dalam POS.

d. Perusahaan harus melaksanakan pengujian internal terhadap bakteri Staphylococcus aureus dari permukaan peralatan yang kontak dengan produk.

e. Program audit sosial dan lingkungan harus segera dilakukan untuk melengkapi hasil audit internal secara keseluruhan.

f. Melakukan pengujian limbah cair dari laboratorium eksternal dengan cara memastikan bahwa peralatan dan mesin pengolahan limbah harus aman, berfungsi dengan baik dan pemeliharaannya harus terjamin.

\section{KESIMPULAN}

Hasil penilaian kesesuaian menunjukkan bahwa PT. XYZ sudah memenuhi $100 \%$ sub klausul kepemilikan hak, $100 \%$ sub klausul sistem manajemen mutu, $75 \%$ sub klausul manajemen karyawan, $100 \%$ sub klausul manajemen limbah dan lingkungan, $93 \%$ sub klausul manajemen keamanan pangan, $90 \%$ sub klausul manajemen verifikasi, $100 \%$ sub klausul sistem ketertelusuran, dan $96 \%$ sudah memenuhi persyaratan tambahan.

To Cite this Paper: Ariadi, P., S., Wahyu, Y., I. 2021. Analisis Pemenuhan Persyaratan Ekolabel Global Aquaculture Alliance - Best Aquaculture Practices (GAA-BAP) di Industri Pengolahan Udang PT. XYZ Sidoarjo. Samakia: Jurnal IImu Perikanan, 12 (2) : $103-$ 114

Journal Homepage: https://journal.ibrahimy.ac.id/index.php/JSAPI 
Rekomendasi perbaikan yang harus dilakukan adalah peningkatan pengawasan fasilitas keselamatan kerja karyawan, melaksanakan program pelatihan penanganan bahan kimia berbahaya, mengimplementasikan prosedur ketahanan pangan, melaksanakan pengujian internal sesuai persyaratan GAA-BAP secara rutin, melakukan audit internal yang mencakup audit sosial dan lingkungan, serta menjamin instalasi limbah dalam kondisi terbaik.

\section{DAFTAR PUSTAKA}

Annonymous. 2018. BAP-Certified Aquaculture Facilities. Melalui http://www.bapcertification.org/CertifiedFacilities. diunduh tanggal 31 Agustus 2018.

Arifin, S. 2013. World Global Fisheries Standard: am Overview. Materi disampaikan pada Apresiasi Inspektur Mutu Kementerian Kelautan dan Perikanan tanggal 22 s.d. 24 Oktober Anyer, Jawa Barat.

Badan Perencanaan Pembangunan Nasional (BAPPENAS). 2016. Kajian Strategi Industrialisasi Perikanan untuk Mendukung Pembangunan Ekonomi Wilayah. Direktorat Kelautan dan Perikanan-Kedeputian Bidang Kemaritiman dan Sumber Daya Alam. Jakarta.

Global Aquaculture Alliance (GAA). 2008. Guidelines for BAP Standards Seafood Processing Plants. St.Louis, USA: Global Aquaculture Alliance. Hal. 15-23

Global Aquaculture Alliance (GAA). 2015. GAA Seafood Processing Standard Issue 4 Revisi 2, December 2015. https:// www.bapcertification.org/ diunduh tanggal 27 Mei 2018.

Ingrid, K., B. N. Noestvold and J. A. Young. 2014. National or Supranational Fisheries Sustainability Certification Schemes? A Crtical Analysis of Norwegian and Icelandic Responses. Marine Policy. Volume 46, Hal.137-142. Doi: 10.1016/j.marpol.2014.01.015.

International Organization for Standardization (IOS). 2000. ISO 14020:2000 Environmental Labels and Declaration-General Principles. IOS.

Kementerian Kelautan dan Perikanan (KKP). 2016. Laporan Tahunan KKP Tahun 2016. Jakarta: Kementerian Kelautan dan Perikanan.

Lee, D. and Conelly, J. 2006. Global Aquaculture Alliance on Best Aquaculture Practices: An Industry Prepares For Sustainable Growth. Sustainable Law and Policy. Fall 2006, Hal. 6062.

Mercan, S.O., and Bucak, T. 2013. The ISO 22000 Food Safety Management System in the Food and Beverage Industry. International Journal of Education and Research. Vol. 1 No. 6

National Seafood HACCP Alliance. 2000. Seafood HACCP Alliance Course: Sanitation Control Procedures for Processing Fish and Fishery Products. First Edition. USA.

Occupational Safety and Health Administration (OSHS).2014. Protecting Workers from Cold Stress. U.S. Department od Labor Occupational Safety and Health Administration. https://www.osha.gov/Publications/OSHA3156.pdf/diunduh tanggal 18 April 2019.

Pramoda, R. dan Putri, H.M. 2017. Penerapan Sertifikasi Aquaculture Stewardship Council (ASC) terhadap Produk Udang Budidaya. Jurnal Borneo Administrator Vol. 13 No. 2: 89-109

Simamora, S.D. 2014. Langkah dan Strategi Ekspor ke Uni Eropa Produk Udang. Market Brief. APINDO-EU Active Project. Jakarta: Asosiasi Pengusaha Indonesia.

Sugiyono. 2010. Metode Penelitian Pendidikan Pendekatan Kuantitatif, Kualitatif, dan R\&D. Bandung : Alfabeta.

U.S.Department of Health and Human Services-FDA. 2011. Fish and Fishery Products Hazard and Controls Guidance. Fourth Edition-April 2011. Florida: USA.

Waluyo, B. 2002. Penelitian Hukum dalam Praktek. Jakarta : Sinar Grafika.

Worksafe Victoria. 2008. A Handbook for Workplaces: Safe Operation of Cold Storage Facilities Edition No. 1 June 2008. https://www.worksafe.vic.gov.au/data/assets/pdf file/0019/10378/

To Cite this Paper: Ariadi, P., S., Wahyu, Y., I. 2021. Analisis Pemenuhan Persyaratan Ekolabel Global Aquaculture Alliance - Best Aquaculture Practices (GAA-BAP) di Industri Pengolahan Udang PT. XYZ Sidoarjo. Samakia: Jurnal IImu Perikanan, 12 (2) : $103-$ 114.

Journal Homepage: https://journal.ibrahimy.ac.id/index.php/JSAPI 
Cold Storage Handbook.pdf /diunduh tanggal 18 April 2019.

Zamrudi, J., Kusumaningrum, H.D., Nuraida,L. 2014. Analisis Pemenuhan Persyaratan Food Safety Certification 22000 di Industri Kemasan Pangan. Jurnal Mutu Pangan Vol. 1 (2): 124131.

To Cite this Paper: Ariadi, P., S., Wahyu, Y., I. 2021. Analisis Pemenuhan Persyaratan Ekolabel Global Aquaculture Alliance - Best Aquaculture Practices (GAA-BAP) di Industri Pengolahan Udang PT. XYZ Sidoarjo. Samakia: Jurnal IImu Perikanan, 12 (2) : $103-$ 114.

Journal Homepage: https://journal.ibrahimy.ac.id/index.php/JSAPI 